\title{
The State, International Agencies, and Property Transformation in Postcommunist Hungary ${ }^{1}$
}

Eric Hanley

University of Kansas

Lawrence King

Yale University

István Tóth János

Hungarian Academy of Sciences

This article challenges evolutionary accounts of property transformation in postcommunist Hungary, which hold that novel property forms based on interenterprise ownership have emerged in that country. It shows that private property has emerged as the predominant category of ownership in Hungary and explains the rapid diffusion of private ownership by focusing on the actions of the state and international agencies such as the International Monetary Fund and the European Union. Following the collapse of communism, state actors in Hungary promoted the domestic accumulation of capital by subsidizing the sale of state enterprises to private parties, particularly enterprise insiders. Pressures from international agencies ultimately forced government officials to abandon this policy, however, and to conform to a neoliberal model of the state that allowed direct foreign investment. The conclusion considers the capacity of states to intervene in economic processes in an environment increasingly dominated by suprastate agencies.

Among sociologists studying Eastern Europe there has been a marked reluctance to label economic change in the region as a "transition to

\footnotetext{
'This research was supported by a grant from the General Research Fund at the University of Kansas. The authors thank Robert Antonio, David N. Smith, David Stark, and Ivan Szelényi for comments on an earlier draft of the paper. Please address all correspondence to Eric Hanley, Department of Sociology, University of Kansas, 716 Fraser Hall, Lawrence, Kansas 66045. E-mail: hanley@ku.edu
}

(C) 2002 by The University of Chicago. All rights reserved. $0002-9602 / 2002 / 10801-0004 \$ 10.00$ 
capitalism." Instead, researchers have preferred to describe developments in the region in terms of evolutionary models that stress organizational inertia and continuity with preexisting institutional forms. ${ }^{2}$ Such "path dependent" approaches highlight the manner in which local actors, as a result of their tendency to resort to familiar routines and practices, reproduce institutions that date back to the state-socialist period (Murrell 1992; Poznanski 1995). Extending the evolutionary approach to the arena of property rights, David Stark (1996) has argued that the managers of state-owned enterprises in Hungary have institutionalized the relations of reciprocity that linked firms during the communist period by establishing networks of institutional cross-ownership, thereby creating a form of "recombinant property" that blurs the traditional distinction between state and private ownership. ${ }^{3}$ Echoing a theme frequently invoked by economic sociologists today, Stark maintains that interenterprise ownership has given rise to forms of economic coordination based as much on reciprocity as competition. Much of the scholarly community has fallen in line behind Stark, accepting the claim that reliance on preexisting routines and practices on the part of local economic actors has resulted in the persistence of organizational forms and institutional practices dating from the state-socialist period (Nielsen, Jessop, and Hausner 1995; Campbell and Pedersen 1996; Eyal, Szelényi, and Townsend 1998; Smith and Pickles 1998).

Despite the support the recombinant property thesis has received within academic circles, we argue that it is empirically incorrect. Focusing on property transformations in Hungary, we will show that the collapse of state socialism in that country has not given rise to hybrid property forms based on institutional cross-ownership. On the contrary, over the past 10 years that country has witnessed the rapid diffusion of private ownership rights. Two developments in particular underlie the transformation of the ownership structure in Hungary: the subsidized sale of state-owned enterprises to domestic parties and the inflow of foreign direct investment (FDI). Taken together, these developments have placed ownership of a large majority of enterprises in the hands of clearly identifiable private parties.

${ }^{2}$ By institutions we mean the rules that provide the framework in which social action takes place. This definition covers not only laws and formal rules but also informal constraints such as conventions and norms of behavior. Organizations, by contrast, refers to groups created to pursue definite goals.

${ }^{3}$ Property rights refer to the rules that define ownership and control of the means of production. Following a number of researchers, we argue that property rights should be conceived as a bundle of distinctive claims pertaining to the right to control the use to which a given set of assets are put, the right to dispose of the income generated by these assets, and the right to transfer these assets. 
In this article, we develop a theoretical perspective that provides insights into the processes whereby domestic and foreign parties have acquired ownership rights over productive assets in Hungary. Drawing on insights from comparative political economy, we explain the diffusion of private ownership rights in Hungary, and in particular the distribution of these rights between foreign and domestic parties, in terms of a contest between the state and international agencies over the course of economic development. As is the case in most developing countries, state actors in Hungary were structurally constrained by their dependence on foreign capital. Taking advantage of this structural dependence, international agencies progressively forced government officials to conform to a neoliberal model of the state that ruled out reliance on the traditional modes of intervention into economic processes and, more specifically, eliminated barriers to FDI in key sectors of the Hungarian economy. Despite constraints imposed by external agencies, however, the state has continued to play an important role in shaping economic developments in Hungary, in large part through the allocation of property rights. State actors in Hungary, we argue, had an interest in promoting the domestic accumulation of capital, which led them to engage in a number of "property rights actions" (Campbell and Lindberg 1990) that explicitly favored national elites at the expense of foreign multinationals. Even though external pressures did eventually force government officials in Hungary to jettison many instruments of economic intervention, state actors in that country nevertheless retained considerable capacity to shape economic developments as a result of their power to allocate ownership rights over productive assets.

Our emphasis on the capacity of state actors to influence economic development even in the face of countervailing pressures is very much in line with contemporary discussions of the developmental state. We focus, however, on a dimension of state capacity that has received little attention in this literature, namely the ability of officials in postcommunist states to use their power to allocate ownership rights over economic assets to further developmental goals. Most studies of postcommunist Eastern Europe, even those conducted by researchers within the developmental state camp, stress the manner in which integration into global and regional markets has diminished the regulatory autonomy of postcommunist states (Amsden, Kochanowicz, and Taylor 1994; Gowan 1995). What these studies have failed to note, however, is that the very requirement to privatize state enterprises has enhanced the capacities of postcommunist states in new ways. By focusing on the property rights actions of government officials, we hope to show that state actors in Hungary played an important role in fashioning that country's integration into the world econ- 
omy despite the constraints imposed by international agencies and foreign capital.

\section{THE RECOMBINANT PROPERTY THESIS}

Among researchers studying economic transformation in Hungary, the general consensus has been that privatization in the postcommunist period has taken place in an environment characterized by weak ownership rights on the part of state actors and strong ownership rights on the part of enterprise insiders. Those who support this interpretation tend to highlight the following developments (Voszka 1993, 1995; Canning and Hare 1994):

1. the adoption of the New Economic Mechanism in 1968, which abolished central plan targets and removed price controls from a broad range of goods and services;

2. passage of the 1984 Law on Enterprise Self-Governance, which placed two-thirds of Hungarian firms under the control of enterprise councils dominated by management;

3. the implementation of 1988 Company Law and the 1989 Transformation Law, which, taken together, permitted the conversion of state enterprises into joint-stock companies and the transfer of up to $20 \%$ of the shares of converted enterprises to insiders at discounted prices;

4. the collapse of state socialism, which resulted in the disappearance of the mechanisms the state had used to assert property rights-the central planning apparatus and the party hierarchy; and

5. the adoption on the part of the first postcommunist government of Josef Antall of a decentralized approach toward privatization that transferred the authority to develop privatization proposals to enterprise directors themselves.

Developments such as these have convinced many observers that the postcommunist state has been unable to administer assets formally under its control (Crane 1991; Frydman, Murphy, and Rapaczynski 1996).

Stark's (1996) recombinant property thesis retains the idea that the collapse of state socialism left de facto ownership rights over state-owned firms in the hands of enterprise directors. Rather than argue that enterprise directors have been able to give their de facto rights a de jure form, however, Stark maintains that they opted for another arrangement-institutional cross-ownership-which allowed them to retain effective control over economic assets while enjoying a number of additional advantages. According to Stark, the "corporatization" of state enterprises, 
that is, their transformation into limited-liability or joint-stock companies, has not given rise to genuine privatization. Instead, the shares of corporatized enterprises were acquired for the most part by other enterprises, often those upstream to or downstream from a given firm; this practice resulted in the emergence of a complex structure of property rights based on dense networks of interenterprise ownership links. Because institutional cross-ownership involved the exchange of shares between nominally state-owned firms, Stark insists that the emergent property rights structure in Hungary cannot be characterized as one based on private ownership. Nor, however, can the rights structure be seen as a disguised form of state ownership, since cross-ownership resulted in the establishment of new governance structures (i.e., boards of directors) made up not of state officials but rather of the managers of those firms that possessed shares of a given company. The result, therefore, has been a novel structure of property rights that involves the blurring of the distinction between state and private ownership in a manner that has enhanced managerial control over productive assets.

Although institutional cross-ownership represented a clear-cut case of organizational innovation, it was nevertheless a type of innovation that involved improvisation on, rather than rejection of, "practiced routines" (Stark 1996, p. 995). For Stark, the most important legacy left behind by state socialism was not the downward devolution of ownership rights to enterprise directors but the persistence of networks of informal relations linking state enterprises to one another. It has frequently been observed that the formal features of the communist command economy -mandatory targets, price controls, the central allocation of inputs and outputs-were in practice complemented by informal relations of reciprocity that helped firms maintain production despite bottlenecks in basic commodities (Kornai 1992). According to Stark, these informal linkages have been institutionalized in the postcommunist period in the form of interenterprise ownership ties and, as such, represent the formalization of the relations of reciprocity that helped coordinate production during the state-socialist period. The implication, of course, is that this form institutional cross-ownership has allowed for the persistence of forms of coordination based on principles of reciprocity rather than those of the market.

Some have suggested that the existence of relations of reciprocity between formerly state-owned firms has impeded rather than facilitated the transition to capitalism by encouraging the growth of interenterprise debt, thereby allowing loss-making firms to remain afloat. While Stark acknowledges that the interenterprise ownership may retard bankruptcy by allowing firms to run up substantial debts, his emphasis is nevertheless on the manner in which institutional cross-ownership promotes rather 
than hinders processes of "creative destruction." First, Stark maintains that the establishment of interenterprise ownership links facilitates the recombination of resources across the boundaries of organizations. Left to their own devices, he argues, few enterprises have the resources needed to survive in a postcommunist economic environment characterized by the loss of traditional markets, the collapse of domestic demand, and intense competition from foreign rivals. Once linked by means of intersecting ownership ties, however, Hungarian firms are able to recombine their resources in innovative ways, enhancing their capacity to respond creatively to market pressures. Second, Stark argues that institutional cross-ownership promotes investment by spreading risk across intertwined firms. Faced with high levels of uncertainty, individual enterprises are disinclined to make the large investments that are necessary to acquire new technology, move into new production lines, or penetrate new markets. By spreading risk, institutional cross-ownership mitigates against disinclinations to invest, thereby creating the possibility of firms breaking out of "low-level equilibrium traps" (Stark 1996, p. 1019). It is important to note that, in making these arguments, Stark is taking aim at the theories of neoclassical economists. In his view, the clarified system of property rights that neoclassical economists favor would impose undue hardship on formerly state-owned enterprises, resulting in the exit of a large number of viable enterprises. Thus it is not the clarity of property rights but their very ambiguity that promotes the flexible adaptation of enterprises to a rapidly changing economic environment (Stark 1996, pp. 1020-21).

Stark's account of recombinant property in Hungary is very much in line with much contemporary research in economic sociology. In recent years, a number of studies have put forward the claim that enterprises regularly enter into interfirm alliances that facilitate the combination of resources across organizational boundaries for the mutual benefit of the participating firms (Piore and Sabel 1984; Powell 1990). Given the parallels between Stark's analysis and the contemporary research on interenterprise networks, it is not surprising that the recombinant property thesis has found a receptive audience. In fact, Stark's notion of recombinant property is arguably the most influential of the sociological accounts of privatization in former state-socialist societies to have emerged. Even empirical studies of property transformation in Hungary remain wedded to Stark's concepts. Eyal et al. (1998), for example, analyzed firmlevel data collected in Hungary in 1996 and concluded that capitalism in that country was being made not by a "propertied bourgeoisie" but rather by a "coalition of propertyless agents" (p. 113), which included the managers who exercised control over state-owned and institutionally crossowned firms (pp. 136-37). Like Stark, these authors suggest that enterprise directors and their allies blocked genuine privatization and have estab- 
lished instead ambiguous property forms that provide many of the advantages of private ownership without the risks. Although Eyal et al.'s work appears to provide empirical support for Stark's claims, we argue that the data tell a different story.

\section{THE POSTPRIVATIZATION PROPERTY RIGHTS STRUCTURE}

Empirical support for the recombinant property thesis comes largely from data collected in Hungary in the early 1990s. At that time, the laws regulating the transformation of state enterprises into joint-stock companies required enterprises undergoing such "corporatization" to sell a portion of their stock to outside parties. Many firms met this condition by exchanging shares with other corporatized state enterprises (Voszka 1993), a process that gave rise to interenterprise ownership networks on a relatively large scale. Initially, therefore, Stark was not alone in arguing that forms of institutional cross-ownership had emerged in Hungary during the years immediately following the collapse of state socialism. A number of Hungarian economists and sociologists shared this view, although few went so far as to argue that inter-enterprise ownership represented a novel property form (Voszka 1990; Matolcsy 1990; Móra 1991).

Since the early 1990s, however, a number of developments have occurred which appear to have halted the initial trend in the direction of institutional cross-ownership. Most important, by the late 1990s officials at various state agencies in Hungary had succeeded in transferring ownership over a large majority of state enterprises to private parties, foreign and domestic. Given the commitment of government officials in Hungary to large-scale privatization, it is unclear that the property rights structure described by Stark and others in the early 1990s survived the decade. An empirical test of the recombinant property thesis thus appears warranted; we accomplish this with an original analysis of two firm-level data sets that contain detailed information on the ownership of medium-sized and large enterprises in Hungary in 1992 and 1997 (Sagi 1993; Szelényi and Kováchs 1998). ${ }^{4}$ Table 1 presents statistics on the ownership of such en-

${ }^{4}$ The data come from two surveys conducted in 1993 and 1998, respectively. The 1993 survey was based on a random sample of all firms included in the Hoppenstadt business register, which is compiled by a German company that has often been used as a sampling frame. Interviews were conducted with the CEOs of the firms sampled. The 1998 data were also drawn from the Hoppenstadt register and, as in 1993, interviews were conducted with the CEOs. The 1998 sample differs from the 1993, however, in that the later sample was restricted to firms whose revenues were greater than 200 million forints. In order to ensure comparability, we have limited the analysis of the 1993 data to firms with revenues at an equivalent level after controlling for inflation. 
TABLE 1

MAJORITY OWNERSHIP OF MEDIUM-SIZEd AND LARGE ENTERPRISES IN HUNGARY

\begin{tabular}{|c|c|c|c|c|}
\hline & \multicolumn{2}{|c|}{ ALL. FIRMS } & \multicolumn{2}{|c|}{$\begin{array}{l}\text { Formerly State- } \\
\text { OWNEd FIRMS }\end{array}$} \\
\hline & . 1992 & 1997 & 1992 & 1997 \\
\hline State $\ldots \ldots \ldots \ldots \ldots \ldots \ldots$ & 45.9 & 17.3 & 65.7 & 27.1 \\
\hline Foreign $\ldots \ldots \ldots \ldots \ldots \ldots$ & 16.8 & 25.6 & 8.1 & 17.3 \\
\hline Domestic individual ... & 24.2 & 39.1 & 13.0 & 35.7 \\
\hline Managers.......... & $\ldots$ & 15.3 & $\ldots$ & 13.7 \\
\hline Employees ........... & $\cdots$ & 7.6 & $\ldots$ & 11.8 \\
\hline Other $\ldots \ldots \ldots \ldots \ldots \ldots$ & $\ldots$ & 16.2 & $\ldots$ & 10.2 \\
\hline Domestic corporate .... & 9.4 & 9.8 & 9.7 & 8.2 \\
\hline No majority ............ & 3.9 & 8.3 & 3.5 & 11.8 \\
\hline Total $\ldots \ldots \ldots \ldots \ldots \ldots$ & 100.0 & 100.0 & 100.0 & 100.0 \\
\hline$N$ of cases $\ldots \ldots \ldots \ldots . . .$. & 673 & 543 & 432 & 255 \\
\hline
\end{tabular}

NotE.-Data are from the 1992 Survey of Managers (Sagi 1993) and the 1997 Survey of Management of Leading Hungarian Companies (Szelényi and Kováchs 1998).

terprises in these years, distinguishing between a number of types of ownership that we discuss in turn. ${ }^{5}$

Foreign ownership. - Table 1 shows that foreign ownership of enterprises in Hungary rose between 1992 and 1997 from $16.8 \%$ to 25.6\%. Analysis of the data indicates that about half of these companies fall into the category of greenfield investments; that is, new facilities established after 1989 that did not incorporate privatized state assets. The other half consist of formerly state-owned enterprises; as table 1 shows, by 1997 foreign parties had acquired majority ownership rights in $17.3 \%$ of formerly state-owned enterprises. Because FDI remains concentrated within a relatively small number of sectors, however, the statistics presented here probably understate the impact that foreign ownership has had on the

${ }^{5}$ Domestic corporate ownership has been treated as a distinct category since the data do not allow for the identification of the owners of these corporations themselves. It is possible, therefore, that domestic corporate ownership may be a disguise for state ownership, since the Hungarian state remains the owner of a sizable number of enterprises. Given the pace of privatization in Hungary, however, it is more likely that the bulk of these domestic corporations are privately owned. Property transformation in the aluminum sector provides an example of the way in which private ownership in Hungary has assumed a corporate form. Based on fieldwork conducted in Hungary, we found that five of the six firms that were producing aluminum products as of 1997 were corporately owned. These corporations, however, were not owned by the state nor were they institutionally cross-owned. On the contrary, they were owned by Hungarian individuals, with a foreign enterprise possessing minority rights in one of the two companies. In this sector, therefore, corporate forms did not act as a mask for state ownership but rather reflected a tendency among individual owners in Hungary to establish corporations in order to reduce their personal liability, as capitalists in most countries do. 
Hungarian economy. It has been estimated, for example, that as of 1995 foreign parties controlled $40 \%$ of manufacturing assets in Hungary and that firms with foreign parties on their list of owners accounted for $60 \%$ of Hungarian exports in that year (Hunya 2000).

Employee ownership.-Hungarian employees have been able to acquire majority ownership rights over the enterprises in which they work in one of two ways. First, the government launched an employee stock ownership program (ESOP) in 1992 that allowed the employees of a state-owned enterprise to establish a special legal entity and subsequently purchase the enterprise using guaranteed loans called "E-credits," which were obtained at below-market rates. By mid-1995, this program resulted in the sale of approximately 200 enterprises in the state's portfolio to ESOP organizations (Lajtai 1997). Second, industrial cooperatives in Hungary were transformed en masse into employee-owned limited-liability or jointstock companies as a result of legislation passed in 1992 mandating their corporatization. Before 1989, thousands of industrial cooperatives operated in such light industries as textiles, clothing, furniture, and handicrafts. After 1992, it was generally employees who obtained shares in corporatized cooperatives according to a formula based on their salary and length of service. ${ }^{6}$ As shown in table 1, by 1997 ESOP and the corporatization of industrial cooperatives together allowed employees to acquire ownership of $7.6 \%$ of all medium-sized and large firms in Hungary and $11.8 \%$ of formerly state-owned firms.

Managerial ownership.-The statistics presented in table 1 indicate that Hungarian managers have not displayed a disinclination to acquire de jure ownership rights over productive assets in Hungary. Researchers who have advanced this claim have failed to consider evidence of extensive participation in the privatization process on the part of the managers of state-owned enterprises. By the mid-1990s, reports had emerged in Hungary that managers were obtaining significant ownership rights over privatized enterprises via ESOP. Voszka (1995), for example, argued that the formulas that determined that distribution of shares of enterprises privatized through ESOP-formulas based on salary, length of service, and the amount of money individuals contributed-resulted in the concentration of shares in the hands of management (see also Róna-Tas 1997). More important, in 1993 the government altered the conditions of the Ecredit program in a manner that explicitly favored managers. Following

- The transformation of industrial cooperatives into employee-owned companies has not received the attention it deserves. The information presented here has been derived from interviews we conducted with managers of these companies, who provided details of the law mandating transformation and the manner in which shares were distributed among employees. 
this change, managers were able to use their companies' assets as collateral for E-credits, a stipulation that allowed them to obtain majority ownership rights over their firms and subsequently use a portion of the companies' profits to meet loan obligations (Lajtai 1997). Soon after the implementation of these changes, Karsai and Wright (1994) investigated nine firms privatized via ESOP and found that managers had acquired more than $50 \%$ of the shares in five of these companies. Our analysis supports the conclusion that the managers of state enterprises have emerged in the postcommunist period as owners of privatized firms. By 1997 former managers had acquired ownership of $15.3 \%$ of all medium-sized to large firms in Hungry and $13.7 \%$ of former state enterprises (see table 1). ${ }^{7}$

Other domestic individuals. - Enterprise insiders were not the only domestic parties to have acquired ownership of state-owned companies in Hungary: as of 1997, 16.2\% of all medium-sized and large firms and $10.2 \%$ of formerly state-owned enterprises were owned by Hungarian citizens who had been neither employees nor managers of the firms they acquired (see table 1). We came across instances of this type of domestic ownership in the course of investigating the aluminum sector. Initially firms in this sector had been placed in the category of long-term state ownership. Following the victory of the Socialists in 1994, however, officials at the State Property Agency (SPA) were instructed to locate buyers for aluminum firms as rapidly as possible. Because interest on the part of foreign multinationals was limited, the SPA had little choice but to sell most of the facilities in question to two companies whose controlling shares were in the hands of a small number of Hungarian individuals. Given the lack of savings among domestic parties, it is reasonable to ask how these individuals were able to generate the sums needed to acquire the companies. The answer is that the SPA sold the firms for an extraordinarily low price. Although the details of the sales remain officially confidential, information leaked to the press indicates that, in one case, a facility that had been responsible for the production of 200,000 tons of aluminumoxide products in 1988 was acquired in 1996 for the forint equivalent of $\$ 50,000$ USD (MTI-Econews 1997a). This action indicates that officials in Hungary were willing to part with firms at very low prices in those instances in which foreign interest was minimal, and this practice appears to have facilitated the transfer of ownership rights over state-owned enterprises to domestic parties.

State ownership. - The percentage of firms owned by the state declined considerably between 1992 and 1997, from $45.9 \%$ to $17.3 \%$ (table 1). Firms that remained state-owned as of 1997 fell into one of two categories:

'The data include the past employment histories of managers, permitting the identification of individuals who had directed state-owned enterprises prior to 1997 . 
enterprises the state was unwilling to privatize and those for which it had not yet located buyers. Research suggests that the majority of the firms that remained state owned as of 1997 fell into the former category. According to Voszka (2000), of the 306 firms that the state owned as of 1998, 180 were in the category of long-term state ownership, and were concentrated in such sectors as agriculture, forestry, and transportation. This left 126 firms for which state officials were actively seeking buyers. Because firms in this latter group have been slated to be sold or liquidated within a few years, it is not unreasonable to expect that the number of mediumsized and large firms under state ownership in Hungary will decline further over time.

No majority owner.-One other category deserves close scrutiny: firms with no majority owner. Supporters of Stark's recombinant property thesis would expect a large number of institutionally cross-owned firms to fall into this category, since shares of such firms are by definition distributed among a number of parties. In fact, a relatively high proportion of firms $(10 \%)$ had no majority owner as of 1997 (table 1). Closer inspection reveals, however, that relatively few of the firms lacking a majority owner were institutionally cross-owned. Our analysis of the 1997 data indicates that a majority of the firms in this category (55.6\%) were of a single type: firms in which managers and employees jointly held majority ownership rights. More than likely, these were firms that were privatized through ESOP after the implementation of changes facilitating managerial participation. Another $24.4 \%$ of the firms without majority owners were jointly held by identifiable private parties, foreign and domestic. Finally, only $10.1 \%$ of firms with no majority owner involved any degree of state ownership. Within this category of ownership, in other words, there is very little evidence of either institutional cross-ownership or the "blurring" of state and private property.

Institutional cross-ownership.-Defenders of the recombinant property thesis may argue that, in and of itself, evidence of large-scale privatization does not amount to a refutation of the recombinant property thesis. They might point out, for example, that even subsequent to privatization, the state may retain minority ownership rights of such magnitude as to place the enterprises in question into the category of recombinant property. This is not an unreasonable proposition since, according to Hungarian law, shareholders who control at least $25 \%$ of a firm's equity have the power to veto vital actions such as mergers, acquisitions, divestments, and changes to the rights attached to different types of shares (Pechota 1990). In many cases, government officials in Hungary announced their intention of maintaining not $50 \%$ but a " $25 \%$ plus 1 " share in a given company since that level of ownership gave the state a considerable voice, if not in the daily operations of the firm, at least in the determination of key 
TABLE 2

Cross-Ownership among Medium-Sized to Large Firms In Hungary, 1997

\begin{tabular}{|c|c|c|c|c|c|}
\hline \multirow[b]{2}{*}{ MAJORITY OWNER } & \multicolumn{5}{|c|}{ MINORITY OWNER } \\
\hline & State & Foreign & $\begin{array}{l}\text { Domestic } \\
\text { Individual }\end{array}$ & $\begin{array}{l}\text { Domestic } \\
\text { Corporate }\end{array}$ & $N$ of Cases \\
\hline \multicolumn{6}{|l|}{ All firms: } \\
\hline State $\ldots \ldots \ldots \ldots \ldots \ldots \ldots$ & . & 3.2 & 2.1 & 3.2 & 94 \\
\hline Foreign $\ldots \ldots \ldots \ldots \ldots$ & 2.2 & $\ldots$ & 10.8 & 5.0 & 139 \\
\hline Domestic individual ... & 2.3 & 10.0 & $\ldots$ & 3.2 & 212 \\
\hline Domestic corporate .... & 3.8 & 11.3 & 7.5 & $\cdots$ & 53 \\
\hline Total $\ldots \ldots \ldots \ldots \ldots$ & 1.8 & 5.0 & 6.0 & 3.4 & 498 \\
\hline \multicolumn{6}{|l|}{$\begin{array}{l}\text { Formerly state-owned } \\
\text { firms only: }\end{array}$} \\
\hline State $\ldots \ldots \ldots \ldots \ldots \ldots \ldots$ & $\ldots$ & 2.9 & 1.4 & 2.9 & 69 \\
\hline Foreign $\ldots \ldots \ldots \ldots \ldots$ & 4.5 & . . & 13.6 & 2.3 & 44 \\
\hline Domestic individual ... & 3.2 & 11.7 & . & 3.2 & 91 \\
\hline Domestic corporate .... & 4.8 & 19.0 & 9.5 & $\cdots$ & 21 \\
\hline Total $\ldots \ldots \ldots \ldots \ldots$ & 2.2 & 6.7 & 6.2 & 2.7 & 225 \\
\hline
\end{tabular}

Note. - Data are from the 1997 Survey of Management of Leading Hungarian Companies (Szelényi and Kováchs 1998). Minority owner has a $25 \%-49 \%$ stake; majority owner has $50 \%$ or more.

decisions. ${ }^{8}$ Because of the ownership rights that the " $25 \%$ plus 1 " rule confers in Hungary, a full test of the recombinant property thesis requires analysis of the distribution of minority ownership rights at this threshold.

Table 2 cross-tabulates firms by majority and minority ownership, with minority ownership set at the $25 \%$ level. Contrary to the recombinant property thesis, only a relatively small percentage of firms $(15.2 \%$ of all firms and $17.8 \%$ of formerly state-owned firms) reported minority holdings at the $25 \%$ threshold as of 1997 . Governance of a large majority of Hungarian firms, in other words, was firmly in the hands of majority owners by that year. Furthermore, our analysis fails to uncover evidence of the interpenetration of state and private property on a significant scale. As of 1997 the state exercised $25 \%$ ownership rights in very few privately owned firms (1.8\%) while foreign companies had $25 \%$ ownership rights in only $3.2 \%$ of firms that were majority state-owned, and domestic individuals held such stakes in only $2.1 \%$ of state-owned firms. On the basis of these findings, it appears safe to say that, by 1997, the property rights structure in Hungary was characterized by clear and unambiguous ownership rights.

It should be noted that recent studies by Hungarian researchers support

${ }^{8}$ Among those firms slated to remain in permanent state ownership in the government's initial decree of October 1992, e.g., the state was expected to retain majority ownership in approximately one-half (61 of 126 enterprises) and " 25 percent plus 1 " ownership in the remainder (MTI-Econews 1992a). 
our conclusion that majority ownership rights over Hungarian firms are generally in the hands of identifiable private parties (Tóth 1997; Csite and Kovách 1999; Major, Vezzoni, and Szalavetz 1999; Mihályi 2000). Our analysis, however, has contributed to the ongoing debate over recombinant property in two ways. First, we have subjected the recombinant property thesis to a more rigorous test than has been undertaken in these recent studies by examining ownership ties at the $25 \%$ threshold according to type of majority owner. Even at this level, we find almost no evidence of the forms of interenterprise ownership described earlier by Stark. Second, we have explicitly assessed the claim regarding the interpenetration of state and private ownership, something existing studies have failed to do. Again, we find little evidence of the hybrid forms of ownership that the recombinant property hypothesis predicts.

\section{AN ALTERNATIVE MODEL OF PROPERTY TRANSFORMATION}

Recent developments in Hungary cast serious doubt on the contemporary relevance of the recombinant property thesis. While forms of interenterprise ownership may have emerged in Hungary during the years immediately following the collapse of communism, the commitment of government officials to dispose of state-owned assets appears to have transformed the property rights structures in ways supporters of the thesis failed to anticipate. In this section we elaborate an alternative theory of property transformation that highlights the role of the state as well as that of international agencies such as the International Monetary Fund (IMF) and the European Union (EU). Any analysis of property transformation in Hungary, we argue, must bring the state to the fore, given its capacity to allocate ownership rights over productive assets and thereby shape economic developments. Such an appreciation for the ability of the state to intervene in economic processes via its property rights actions must be balanced, however, by the recognition that pressures imposed by international agencies such as the IMF and the EU may limit the state's autonomy in the economic arena. Our purpose in this section, then, is to outline a theory of property transformation in Hungary that both recognizes that integration into global and regional markets has diminished the regulatory autonomy of the Hungarian state in many ways, and acknowledges that Hungarian state actors have nevertheless retained a capacity to intervene decisively in economic processes through their property rights actions.

Our effort to explain the course of privatization in Hungary incorporates three basic insights from the literature on comparative political economy. We start with a proposition that is repeated often in this literature: in 
order to promote the domestic accumulation of capital, the state frequently adopts policies that favor local elites at the expense of foreign multinationals. Evan's (1979) analysis of dependent development addresses this theme with particular clarity. The main elements of his argument can be summarized as follows. State actors have a vested interest in promoting the domestic accumulation of capital since the state's own resources are drawn largely from the local economy. In developing countries, however, the state's interest in domestic development often clashes with the determination of multinational corporations to repatriate locally generated profits to promote their global business strategies. Because local elites typically lack the organizational capacity to pursue international strategies and thus have little choice but to improve their market position by investing locally, there tends to be a greater coincidence of interests between the state and local business elites than between the state and foreign capital. For these reasons, states in developing societies typically adopt a two-pronged developmental strategy, the first of which involves the application of pressures on multinationals to invest locally and to involve domestic producers in their production activities, the second of which involves a variety of efforts to promote the economic activities of local business elites. As we shall demonstrate, state actors in Hungary accepted this logic and, we will argue, for good reasons.

The determination of state actors in Hungary to implement privatization policies that favored domestic parties provoked a strong reaction on the part of international agencies. In order to assess the capacity of such organizations as the IMF and EU to affect the course of privatization in Hungary, we turn to our second insight: Haggard's (1995) notion of "deep integration." In his analysis of the incorporation of developing nations into the global economy, Haggard distinguishes between "shallow integration," by which he means the relaxations of restrictions on trade and macroeconomic stabilization, and "deep integration," the harmonization of rules governing foreign direct investment, competition, industrial policy, and other forms of economic regulation. According to Haggard, shallow integration is often embraced by domestic coalitions who have an interest in liberalizing the economy. However, developing countries only adopt a "deep integration agenda" when confronted by "powerful economic and political constraints" (Haggard 1995, pp. 6-7). On Haggard's list of constraints are three types of pressure that are relevant for Hungary: an external debt burden, lending policies pursued by international financial institutions, and bilateral pressures applied by such entities as the EU. In the case of Hungary, these external forces worked in unison, pressuring state actors to establish in short order an open market economy in which foreign investments were both welcome and secure.

The last insight from the literature on comparative political economy 
involves the "property rights actions" of states, or, more specifically, the observation that states frequently influence the governance of economic sectors by manipulating property rights (Campbell and Lindberg 1990; Fligstein 1996). Over the years, political economists have highlighted a number of ways in which states intervene in the construction and maintenance of markets, for example, by directing investment, subsidizing industries, erecting tariff barriers, and imposing currency and price controls (Moran 1974; Becker 1983; Bennett and Sharpe 1985). As Campbell and Lindberg (1990) point out, however, the capacity of states to influence economic processes through the manipulation of property rights has not received the scholarly attention it deserves. Focusing on developments in the United States, they show that state actors have frequently engaged in property rights actions in order to transform "governance regimes"-the specific combinations of organizational forms (markets, hierarchies, associations, and networks) that coordinate economic activity among firms in a given sector. Campbell and Lindberg draw two important conclusions from their analysis: first, that the state is capable of exerting a pronounced influence on economic processes through the manipulation of property rights alone, and second, that the definition of property rights is a continuously contested process given the capacity of the state to alter conditions of ownership (see also Fligstein 1996). An emphasis on the property rights actions of the state is crucial for an understanding of developments in Hungary: the conformity to standards imposed by such agencies as the IMF and EU restricted the range of policy options open to government officials, leaving the allocation of property rights as the most effective instrument in their arsenal for affecting economic developments.

Taken together, we believe these insights constitute a comprehensive theory of property change in Hungary. The notion of deep integration highlights not only the determination of international agencies to open the country to FDI but also the methods those agencies use to achieve this end. The theory of dependent development reminds us that, even in the face of such pressure, states continue to make efforts to promote domestic accumulation. Finally, the emphasis on the property rights actions of states ties the first two theoretical strands together. Because the Hungarian state retained formal ownership over most productive assets in that country after 1989, state actors were able to influence economic developments through the preferential allocation of property rights to domestic parties despite the constraints imposed by international agencies such as the IMF and EU.

It should be noted that, up to this point, the theoretical framework we have proposed does not specify the relative strength of the two parties in question-the state and international agencies-in determining economic policy. The role of the state in the global economy is of course an issue 
that is of considerable interest to researchers in a number of disciplines. Although a number of distinct approaches have been put forward, three perspectives appear to dominate the discussion. At one extreme are researchers who argue that globalization has created a "borderless" world in which the efforts of states to manage economic processes are at best futile and at worst dysfunctional (Ohmae 1990). A somewhat less extreme position but one that still posits a considerable loss of capacity on the part of states is what has been termed the "competition state" perspective (Stopford and Strange 1992; Cerny 1993). According to this view, growing competition for investment has forced states to abandon most of the interventionist policies used in the past, to follow neoliberal principles in regard to competition, trade, monetary, and fiscal policy, and to improve the overall economic climate by investing in education and infrastructure. A sizable number of researchers, however, argue that states in the global economy retain far more capacity to intervene in markets than the competition state model allows. According to the "developmental state" perspective, for example, contemporary governments do not simply enforce neoliberal arrangements. On the contrary, they play a central role in fostering domestic development through an assortment of "protective and promotional policies" that systematically violate neoliberal principles regarding the role of the state in the economy (Wade 1990; see also Amsden 1989; Johnson 1982; Evans 1995).

The theoretical framework outlined here falls broadly into the developmental state camp. It should be noted, however, that such an approach has not been favored by researchers examining economic transformations in postcommunist Eastern Europe. On the contrary, the consensus has been that, because of the ideological climate in the years immediately following the collapse of communism as well as pressures from international agencies such as the IMF, state actors in postcommunist Eastern Europe rejected developmental models-such as those pioneered by East Asian countries-in favor of neoliberal model that largely restricts the state's role in the economy to the enforcement of property rights and the removal of impediments to private enterprise (Amsden et al. 1994; Campbell and Pedersen 1996). ${ }^{9}$ We argue, however, that in the case of Hungary

\footnotetext{
${ }^{9}$ Campbell and Pedersen (1996) argue that progressive conformity to the neoliberal model was the result of normative processes rather than coercive pressures. In their view, Western governments, foreign universities, and international agencies persuaded postcommunist governments in the region to adopt neoliberal principles by organizing conferences, providing advisors, generating publications, and financing educational activities. Largely as a result of these "cultural and associational" processes, postcommunist governments in such countries as Poland, Czechoslovakia, and Hungary enacted a remarkably similar set of policies in the early 1990 s, embracing in particular those elements of the shock-therapy program advanced by Western economists that
} 
such an emphasis on conformity with a neoliberal model of the state is misplaced. As our analysis will show, state actors in that country were far from being instrumentally incapacitated. Even as they pushed through legislation that progressively opened the country to global markets, government officials in Hungary continued to play a central role in fostering domestic accumulation through their property rights actions.

\section{COERCIVE PRESSURES}

Although their focus is on the ability of states to influence economic processes, developmental state theorists nevertheless acknowledge the constraints under which state actors operate. As is regularly noted in the literature, the capacities of states to intervene in market processes are far from absolute and, in many instances, states have lost recourse to instruments widely utilized in the past (Boltho 1996; Helleiner 1994). Furthermore, the range of policy options available to state actors varies considerably, due in large part to the extent to which a given country is integrated into international markets (Held et al. 1999). In order to understand the choice of instruments available to state actors, therefore, it is necessary to examine closely the types of external pressures to which they have been exposed. In the case of Hungary, we follow Haggard (1995) in highlighting three sources of pressure in particular: an external debt burden, the lending policies of international financial institutions, and bilateral pressures from the EU.

\section{Foreign Debt}

Hungary found itself in 1989 with the highest per capita debt in the world. In that year, net external debt stood at about $\$ 16$ billion, or about $50 \%$ of GDP (World Bank 1995, p. 1). Most of this took the form of state debt

pertained to macroeconomic stabilization and the liberalization of prices and trade. In discussing the diffusion of neoliberal principles in Eastern Europe, however, it is important to note that consensus in regard to the legitimacy of these principles never extended to the privatization of state enterprises. Because postcommunist governments could ill afford the political fall-out that would accompany plant closures, postcommunist governments in Poland, Hungary, and Czechoslovakia adopted gradualistic approaches toward privatization that involved the extension of subsidies and credits to enterprises. Such approaches deviated from those proposed by international agencies such as the IMF and the World Bank, which advocated rapid privatization, the immediate hardening of enterprise budget constraints, and the liquidation of loss-making firms. Far from converging toward a standard model as a result of normative pressures, postcommunist governments in Eastern Europe generally resisted such pressures and implemented privatization policies that diverged substantially from the neoliberal model (King 2000, 2002). 
to private banks as opposed to international lending agencies, which ruled out the possibility that the debt, or at least a portion of it, would be forgiven. Nor was default an option, since such a move would have cut Hungary off from further credit from both institutional and private lenders. Finally, officials in the first postcommunist government decided against renegotiating the debt on the grounds that this would have lowered Hungary's credit rating and eliminated Hungary's chances of participating in certain loan programs (Denton 1990). Faced with this set of circumstances, Hungarian officials had little choice but to repay the debt as scheduled.

This decision led to a new question: How was the government to obtain the revenue to meet Hungary's debt obligations? The amount of money needed to satisfy these obligations was sizable, particularly in light of the recession that followed the collapse of communism. The solution that government officials devised was to divert revenues obtained from the privatization of state enterprises toward the repayment of the international debt. In January 1990, the first postcommunist government of Jozef Antall announced that $85 \%$ of privatization revenues would be channeled toward the repayment of state debt (MTI-Econews 1990a). This policy had a number of implications, not all of which met with popular approval. For one, the government's need for revenue ruled out the restitution of physical assets to previous owners or their descendants. In the months following the first elections, the Smallholder's Party (a member of the governing coalition) was pressing the government to implement precisely this kind of program. Spokespersons for the prime minister ruled this out, arguing in no uncertain terms that state-owned assets were not to be given away but rather exchanged for cash (MTI-Econews 1990b). ${ }^{10}$ More important, the decision to use privatization as a means of obtaining needed revenue implied that a significant number of state-owned enterprises would be sold to foreign multinationals for the simple reason that Hungarian individuals and firms had very little capital at their disposal. Thus, despite considerable domestic resistance to the idea of selling state enterprises off to the highest bidder, the Antall government made no effort to disguise the fact that its privatization policy involved a concerted effort to attract foreign capital. On the contrary, the stated goal of the government was to sell $25 \%-30 \%$ of state-owned enterprises to foreign parties within five years (MTI-Econews 1991). In order to translate this policy into practice,

${ }^{10}$ The government's position on restitution softened somewhat over time. Although it never countenanced the return of physical assets, it did compromise by providing individuals who had lost property after the communist seizure of power-as well as those who had been persecuted for political reasons-compensation vouchers that they could use to obtain land or shares in privatized enterprises. 
the government quickly passed a number of bills, among them generous tax reductions for foreign investors (World Bank 1995).

\section{International Financial Institutions}

There is a substantial literature detailing the pressures international financial institutions have imposed upon states, particularly states in less developed societies. In order to obtain funding from such institutions, state governments are regularly required to meet strict targets regarding budget and current account deficits as well as to engage in various types of restructuring involving, for example, the privatization of state enterprises and the reform of financial institutions. In the case of Hungary, two institutions in particular head the list of agencies that have put pressure on successive governments to privatize state-owned enterprises and open the country to foreign investment: the IMF and the European Bank for Reconstruction and Development (EBRD).

Discussions of the ability of international lending agencies to force changes in governmental policies generally begin with the IMF, and for good reason. It is not only the material support that the agency itself provides that makes its role so important but also the fact that governments have to maintain good relations with the IMF in order to obtain resources from other sources, including private capital markets. The link between IMF approval of a given country's fiscal policies and that country's access to external resources is often explicit; Hungarian access to $\$ 300$ million dollars worth of loans from the World Bank and the Japanese Eximbank in 1990, for example, depended on the satisfactory conclusion of negotiations with IMF officials (MTI-Econews 1992a). In addition, the cost of raising capital from private sources is directly linked to the status of a given country vis-à-vis the IMF. Those that are in good standing with the agency are rewarded with favorable credit ratings from organizations such as Moody's, reducing the costs of raising capital in international markets, while those in poor standing see their credit rating fall and the costs of raising capital climb precipitously. IMF disapproval of a government's fiscal and budgetary programs can thus effectively eliminate any chances of obtaining capital from either institutional or private parties, a fact of which successive Hungarian governments were well aware (Kornai 1997).

There is another important point regarding IMF policies in Hungary that deserves mention: the IMF targets regarding budget deficits and current account balances were directly linked to privatization. IMF officials made very clear their conviction that the rapid privatization of state-owned enterprises was essential if the Hungarian government was to stay within agreed-upon targets. For example, the privatization of state 
enterprises involved a reduction of subsidies to enterprises as well as the removal of a large number of workers from the state payroll. Both of these outcomes reduced pressure on the state budget. In addition, the sale of state enterprises to foreign parties increased the amount of capital flowing into the country relative to that flowing out, reducing the current account deficit. IMF officials therefore advised Hungary on repeated occasions to divest itself of productive enterprises as rapidly as possible and to open the country to foreign investment (Wapenhans 1990). Thus, even though the formal targets to which the Hungarian government pledged to abide did not refer directly to privatization, the effort to attain these targets nevertheless implied not only the rapid privatization of state enterprises but also the sale of these enterprises to foreign parties.

Like the IMF, the EBRD was committed to the establishment of an economy based on the free trade of goods and services and the private ownership of the means of production. What this implied for Hungary was the privatization of state-owned enterprises, the establishment of corporate governance structures, the enactment of bankruptcy and competition laws, and the reform of financial institutions (Aghion 1991). Acting on these principles, the EBRD intervened in a very direct fashion in the privatization process, assuming the role of "strategic investor" by injecting capital into firms, thereby acquiring minority ownership rights and a seat on the boards of directors. The EBRD relied on this strategy extensively in Hungary; between 1991 and 1996 it purchased more than $\$ 1$ billion worth of equity in some of the country's most visible companies in such sectors as pharmaceuticals, chemicals, automobile manufacturing, textiles, hotels, and retail trade (MTI-Econews 1997b). Furthermore, in 1995 the EBRD became involved in the privatization of Hungary's banks, utilizing the same strategy that had been applied to other enterprises, namely the acquisition of minority ownership rights to assist restructuring and to attract additional outside investors (MTI-Econews 1997c).

\section{Membership in the European Union}

Each of the governments that has ruled Hungary since the collapse of state socialism has had as one of its main goals entry into the EU (Denton 1990). The reasons underlying this position are not difficult to discern. In the view of government officials, the long-term growth of the Hungarian economy hinged upon admission to the union. Among government offcials, the benefits of such membership were impossible to ignore: the inflow of investment, higher wages, and funds for environmental clean-up, infrastructure, health care, and education (World Bank 1999). These benefits came at a considerable cost, however. In particular, admission into the $\mathrm{EU}$ required the Hungarian government to observe strict limits regarding 
budget deficits and the size of the public debt, and furthermore, to bring legal and regulatory codes into line with EU standards. Both of these requirements affected the Hungarian government's policies toward privatization.

There is no need to discuss here the manner in which the EU's budgetary and debt targets provided Hungarian officials with an incentive to dispose of state enterprises to foreign parties; this argument has already been laid out in the discussion of pressures emanating from the IMF. It should be noted, however, that the EU's standards in regard to the size of the budget deficit were considerably more stringent to those adopted by the IMF. ${ }^{11}$ In addition, one of the preconditions of admission into the EU was the full "harmonization" of political, legal, and regulatory practices. Such harmonization required prospective members to bring their political and legal systems into full conformity with EU standards. In and of itself, this was no mean feat; the list of standards to which a given country is required to conform fills many volumes and covers such matters as rules governing elections, environmental regulations, trade policies, the structure of the legal system, tax codes, the provision of pensions and health care, and so on. In regard to privatization and foreign participation in the economy, harmonization required convergence with EU standards regarding such issues as corporate governance, the protection of the rights of minority shareholders, the sanctity of investments, the repatriation of profits, bankruptcy and competition policy, and the reform of financial institutions (European Commission 1995). While EU officials have been somewhat tolerant of failure to stay within budgetary targets, they have taken a hard line in regard to issues pertaining to legal and regulatory harmonization. Nothing short of full convergence has been acceptable to EU commissioners (Bobinski 1997).

Since 1989, postcommunist governments in Hungary have progressively brought the country into compliance with the EU. By 1997, the country had largely achieved harmonization with EU standards, as evident in a report published by the European Commission (1999) that commented favorably on Hungary's efforts. Furthermore, the rules to which the EU required Hungary to conform are consistent with the neoliberal model of the state promoted by the IMF and EBRD, in the sense that compliance with EU standards explicitly ruled out many forms of state intervention in market processes. EU standards are designed to facilitate the free flow of goods, services, and capital across the borders of member states and to allow firms based in one member state the freedom to operate within the territory of another member state. In practice, observance of these

${ }^{11}$ Whereas the IMF typically encouraged governments to bring the state deficit below $5 \%$ of GDP on an annual basis, the EU has preferred a $3 \%$ benchmark. 
standards has ruled out recourse to policies on which states have historically relied to promote domestic development. For example, in order to remain in accordance with EU standards, the Hungarian state was required to eliminate prohibitions on FDI, to remove restrictions on the repatriation of profits through such devices as currency controls or discriminatory taxation, to break down tariff barriers with other EU members, and to enforce competition laws that greatly limited the government's capacity to support domestic firms by means of direct subsidies, soft loans, export credits, or favorable treatment in the area of government procurement (World Bank 1999).

In sum, the external pressures that government officials in Hungary confronted during the 1990s did not push in divergent directions but worked in unison toward establishing in as short a time frame as possible a functioning market economy in which foreign investments were both welcome and secure. Homogenization with EU standards, for example, explicitly excluded the possibility of state actors using taxes, tariffs, currency controls, restrictions on the repatriation of profits, or prohibitions on direct foreign investment to promote domestic development. Fiscal targets imposed by the IMF and EU placed strict limitations on the ability of state actors to direct investment toward firms in certain sectors and, in addition, encouraged the sale of state enterprises to foreign parties in order to reduce budget and current account deficits. Finally, the obligation to repay the debt incurred by communist governments further pressured state actors into selling enterprises to foreign multinationals in order to channel proceeds toward the repayment of privately held debt. Taken together, these external pressures effectively denied government officials access to most of the instruments states have used to foster local industries. One instrument of economic intervention, however, was not strictly regulated by the international agencies in question: the allocation of ownership rights over state-owned enterprises. Denied other means of intervention, state actors in Hungary relied greatly on property rights actions in an effort to influence economic developments in the country. It is to this story that we turn next.

\section{CHANGING PRIVATIZATION POLICIES IN HUNGARY}

In this section we describe in more detail the manner in which external pressures affected the course of privatization in Hungary. The entire privatization process can be roughly divided into three periods: an initial period from 1990 to 1992 during which the need to channel privatization revenues toward the repayment of the external debt led to determination on the part of the government to promote the sale of state enterprises to 
foreign multinationals, an intermediate period from 1993 to 1994 during which domestic resistance to the sell-off of enterprises to foreigners led the government to implement a set of policies that subsidized the sale of enterprises to domestic parties but in turn resulted in the deterioration of external support for the government's policies, and the final period from 1995 to 1997 during which the socialist government of Gyula Horn gave in to international pressures and accelerated the privatization process, including the privatization of firms in the financial, energy, and telecommunications sectors. With this, the privatization process in Hungary was largely completed, with foreign capital dominating key sectors of the economy, domestic owners holding a sizable number of businesses particularly in labor-intensive sectors of the economy, and the state left in control of a few hundred firms concentrated in such sectors as defense, steel, transport, and agriculture.

\section{The Initial Phase, 1990-92}

As noted, the obligation to meet debt obligations inherited from the socialist regime forced the first postcommunist government of Jozsef Antall to implement a privatization policy that emphasized the sale of stateowned enterprises to foreign parties. This policy was a successful one, for a time, with foreign capital responding quickly to the government's efforts to raise hard currency via the sale of state-owned enterprises. As table 1 shows, foreign buyers dominated the privatization process during the first years of postcommunist rule; in 1991, for example, sales to foreign parties accounted for more than three-quarters of the privatization proceeds for that year, and in 1992 for more than half of these proceeds. A total of $\$ 6$ billion of foreign investment entered Hungary between January 1990 and January 1993, making Hungary the largest recipient of foreign investment in Eastern Europe in per capita terms (World Bank 1995, p. 151). While much of this capital inflow took the form of greenfield investment in new production facilities, a sizable proportion involved the sale of existing enterprises to multinational corporations; by the end of 1992, approximately half of FDI had gone toward the purchase of formerly state-owned enterprises (van Elkin 1998b). As promised, much of this revenue was channeled toward the repayment of the state's external debt. In 1991 alone, the equivalent of $\$ 200$ million in privatization revenues was used for this purpose (van Elkin 1998b).

One result of this massive infusion of FDI was the transfer of control of entire sectors of the economy to foreign multinationals. The tobacco industry is a perfect example. Under state ownership as of 1990 , firms in the tobacco sector attracted a great deal of foreign attention due to the desire of foreign multinationals to take advantage of cheap Hungarian 
labor and to acquire market share in a country containing a sizable number of cigarette smokers. Firms such as R. J. Reynolds quickly made their interest known to the SPA, which in turn began to invite tenders on tobacco-processing and cigarette-manufacturing plants in 1991 in accord with new policies that permitted investor-initiated transformations. Within a year, all of Hungary's tobacco and cigarette companies had been sold (for a total price of $\$ 200$ million) to the multinationals that dominated the global production of cigarettes (MTI-Econews 1993a). The same process was at work in other sectors producing consumer goods; within four years, foreign capital effectively dominated segments of the Hungarian economy such as food processing and cosmetics (Lajtai 1997).

Not surprisingly, the readiness of the Hungarian government to part with state enterprises met with the support of international agencies. The IMF demonstrated its approval by extending a $\$ 1.6$ billion loan to Hungary in 1991, to be released in tranches conditional upon the government's capacity to stay within IMF-imposed targets. More important, the overt vote of confidence that international agencies gave Hungary helped the country earn a solid credit rating. This, combined with the fact that the inflow of foreign capital had radically improved Hungary's current account balance, allowed the country to continue to obtain capital from private sources at a relatively low cost, a favorable development for a country like Hungary, which acquired the bulk of the funds it needed not from institutional lenders but rather from private sources (World Bank 1995).

At the same time as the Antall government was bolstering Hungary's standing in the eyes of the international financial community, it was also making efforts to satisfy the EU's demands regarding harmonization. Since the first postcommunist government took office in 1990, Hungarian officials had gone to great lengths to achieve legal and regulatory harmonization. As early as 1990, parliament established a special commission to ensure that new legislation was in line with EU standards (MTI-Econews 1997e). In 1991, Hungary and the EU signed an association agreement that reduced tariffs on the export of Hungarian goods to EU countries in exchange for a commitment on the part of the Hungarian government to continue down the road toward full harmonization. In many areas, such as laws pertaining to corporate governance and bankruptcy, convergence with EU standards was obtained by 1991 (Mills 1991).

Despite the fact that Hungary was rewarded for its conformity to international standards, not everyone in the country supported the government's efforts. In fact, resistance to such conformity emerged very early, even within governmental circles. As noted above, representatives from the Smallholder's Party objected to the fact that the government's policy of channeling privatization revenue toward the repayment of the external 
debt ruled out the possibility of restituting physical property to its original owners. Even one of the vice presidents of the Hungarian Democratic Forum, the ruling party, objected in 1992 to the "sell-out" of state property to foreign parties (Robinson 1992). As time went on, domestic opposition to the government's privatization policy grew, particularly since the improved standing of the government in the eyes of the international financial community did not coincide with improvements in its citizens' standard of living. On the contrary, progress along the privatization front was matched by further economic declines. In 1991 alone, GDP fell by $11.9 \%$ (World Bank 1995, p. 2). Under such conditions, it is not surprising that public discontent translated into a shift in the government's privatization policies away from an emphasis on cash sales to foreign multinationals and toward the subsidized sale of enterprises to domestic parties.

\section{The Intermediate Phase, 1993-94}

Opposition to foreign domination of the privatization process within the ruling coalition in Hungary resulted in a change of course during this period, involving specifically the establishment of restrictions on foreign ownership of firms in key economic sectors such as banking, energy, and telecommunications and the implementation of policies promoting the sale of state enterprises to domestic parties. The capacity of the Hungarian government to accomplish these goals was predicated on the fact that it had taken a number of moves in 1992 to reassert its control over stateowned assets. In particular, government officials had obtained passage of legislation that required state-owned enterprises to "corporatize" (i.e., to transform themselves into limited-liability or joint-stock companies) by January 1, 1993. In practice this meant that the SPA obtained the right, previously exercised by enterprise councils made up jointly of workers and managers, to appoint and remove directors. In addition, the mandatory corporatization law provided the state with a lever of control over the thousands of limited-liability and joint-stock companies that had been legally established by enterprise insiders since the passage of the 1989 Transformation Law. Prior to mandatory corporatization, managers had exercised considerable control over many of these "satellites" since the holding companies that controlled these satellites were governed by enterprise councils under their direction. By abolishing these councils, the mandatory corporatization law effectively transferred to the SPA property rights not only over state enterprises themselves but also over the many thousands of new companies that had emerged alongside state enterprises (Voszka 1995).

In 1992, the government also began its bailout of Hungary's six largest commercial banks, purchasing debt and injecting enormous sums of 
money into the banks in exchange for equity. As a result of this debt-forequity swap, the state (through the Ministry of Finance) once again came to exercise majority ownership rights over Hungary's major banks. This in turn gave government officials enormous leverage over state-owned enterprises, allowing them to extract concessions from enterprise directors before extending new credit (Voszka 1994). Finally, 1992 saw the passage of legislation creating a special agency, the State Asset Management Company (SAMC), to oversee the activities of hundreds of firms that were designated to remain under long-term state ownership. Firms slated for long-term state ownership included some of the largest enterprises in Hungary in such sectors as metallurgy, engineering, energy, telecommunications, chemicals, and pharmaceuticals. Taken together, the enterprises under the control of the SAMC accounted for more than half of all stateowned assets (Voszka 1995, p. 298). Although outside investors were welcome to purchase stakes in these companies, the legislation that established the SAMC required the state to retain significant ownership rights for the foreseeable future, a requirement that effectively discouraged outside investment. Furthermore, the state's power to intervene into the affairs of firms placed under long-term ownership was pronounced. The SAMC, for example, not only had the right to hire and fire managers but also to set prices on outputs and to redistribute income among firms in a given sector (Voszka 1995; see also Canning and Hare 1994).

These efforts to "renationalize" state-owned enterprises set the stage for a shift in governmental policies in the direction of promoting domestic ownership of productive assets. The first signs that the government was changing its tune came in early 1992, when the minister responsible for privatization called for an increase in domestic involvement in the privatization process (MTI-Econews 1992a). Statements such as these were followed later that year by an expansion of the E-credit program, which involved the provision of loans at below-market prices for the purchase of state enterprises. Such credits were initially restricted to individuals participating in the first "self-privatization" program of 1991, which had involved the sale of a few hundred small and medium-sized enterprises. In January 1992, however, ceilings on the amount of money that could be loaned were scrapped, allowing domestic parties to use these credits to purchase large as well as small enterprises. ${ }^{12}$ The circle of those eligible to participate in the program was also widened to include workers and managers who wished to purchase firms through employee stock-own-

${ }^{12}$ Buyers had to provide $2 \%$ of the purchase price of firms up to 5 million forints (equal to the equivalent of $\$ 60,000$ at 1992 exchange rates) and $15 \%$ of the amount over 5 million forints. In the case of large firms, therefore, E-credits could be used to cover approximately $85 \%$ of the purchase price (MTI-Econews 1993b). 
ership programs. Foreigners, however, were excluded from the program (Canning and Hare 1994). Finally, in order to make the program even more attractive to potential buyers, the government established a threeyear grace period on the repayment of loans and lowered the interest rate from $20 \%$ in January 1992 to $7 \%$ by December 1992. With inflation running at $23 \%$ in 1992 , interest rates on E-credits were negative by a very large margin, which in effect meant that the government was subsidizing the sale of state enterprises to domestic parties (MTI-Econews 1992b).

The government also promoted the sale of state-owned enterprises to Hungarian citizens by allowing them to purchase firms with compensation vouchers rather than cash. Compensation vouchers were originally given to individuals who had lost property during the communist period or who had been subjected to political persecution. By the end of 1994, 1.5 million Hungarians had been provided with vouchers with a nominal value of 110 billion forints, or approximately 1 billion in U.S. currency at 1994 exchange rates (MTI-Econews 1994). The problem that many of the holders of these coupons faced, however, was a lack of attractive investment opportunities. Initially, the number of firms whose shares could be purchased on the Budapest Stock Exchange in exchange for coupons was very limited. As a result, a secondary market in compensation coupons developed; by the end of 1994, the market value of these coupons stood at less than $40 \%$ of their original face value (MTI-Econews 1994). Beginning in 1993, however, the government allowed Hungarian citizens and ESOP organizations to purchase state enterprises with compensation vouchers up to a certain percentage of the purchase price, typically $20 \%-40 \%$. The government accepted these compensation vouchers at their face value, and, once again, foreigners were excluded from the program (MTI-Econews 1995a). Thus, while average citizens lacked opportunities to invest their coupons profitably and foreign parties were prohibited from exchanging them altogether, enterprising Hungarians were able to acquire state-owned firms at a considerable discount by purchasing coupons at less than half their nominal value on the secondary market and then redeeming them with the SPA at their full value. Since compensation coupons did not represent real revenue, the practice of accepting these coupons in exchange for ownership of enterprises represented another way in which the acquisition of economic assets on the part of Hungarian citizens was subsidized by the state.

Table 3 displays the cumulative effects of the government's new privatization policies. Not surprisingly, the refusal to countenance the sale of firms in key economic sectors to multinational corporations eventually slowed foreign sales to a trickle. In 1993, for example, sales to foreign parties were the equivalent of more than a billion U.S. dollars and rep- 
TABLE 3

Revenues from Privatization, in Billions of Forints

\begin{tabular}{|c|c|c|c|c|c|c|c|c|}
\hline Revenue & 1991 & 1992 & 1993 & 1994 & 1995 & 1996 & $\begin{array}{c}\text { Jan-June } \\
1997\end{array}$ & Cumulative \\
\hline Total & 31.4 & 74.3 & 173.8 & 130.3 & 474.0 & 158.0 & 119.6 & $1,162.1$ \\
\hline Cash ............... & $\begin{array}{c}30.3 \\
(96.5)\end{array}$ & $\begin{array}{c}63.0 \\
(84.8)\end{array}$ & $\begin{array}{l}134.9 \\
(77.6)\end{array}$ & $\begin{array}{c}36.8 \\
(28.2)\end{array}$ & $\begin{array}{l}451.6 \\
(95.3)\end{array}$ & $\begin{array}{l}113.9 \\
(72.1)\end{array}$ & $\begin{array}{l}112.5 \\
(94.1)\end{array}$ & $\begin{array}{l}943.6 \\
(81.2)\end{array}$ \\
\hline Foreign & & & & & & & & \\
\hline exchange ... & $\begin{array}{c}24.6 \\
(78.3)\end{array}$ & $\begin{array}{c}41.0 \\
(55.2)\end{array}$ & $\begin{array}{l}110.7 \\
(63.7)\end{array}$ & $\begin{array}{l}12.9 \\
(9.9)\end{array}$ & $\begin{array}{l}412.1 \\
(86.9)\end{array}$ & $\begin{array}{c}77.5 \\
(49.1)\end{array}$ & $\begin{array}{l}83.8 \\
(70.1)\end{array}$ & $\begin{array}{l}763.1 \\
(65.7)\end{array}$ \\
\hline Forint & $\begin{array}{c}5.7 \\
(18.2)\end{array}$ & $\begin{array}{c}22.0 \\
(29.6)\end{array}$ & $\begin{array}{c}24.2 \\
(13.9)\end{array}$ & $\begin{array}{c}23.9 \\
(18.3)\end{array}$ & $\begin{array}{l}39.5 \\
(8.3)\end{array}$ & $\begin{array}{c}36.4 \\
(23.0)\end{array}$ & $\begin{array}{c}28.7 \\
(24.0)\end{array}$ & $\begin{array}{l}180.5 \\
(15.5)\end{array}$ \\
\hline Credit & $\begin{array}{c}1.0 \\
(3.2)\end{array}$ & $\begin{array}{c}9.1 \\
(12.2)\end{array}$ & $\begin{array}{c}21.7 \\
(12.5)\end{array}$ & $\begin{array}{c}29.3 \\
(22.5)\end{array}$ & $\begin{array}{c}3.9 \\
(0.8)\end{array}$ & $\begin{array}{c}2.4 \\
(1.5)\end{array}$ & $\begin{array}{l}.3 \\
(.2)\end{array}$ & $\begin{array}{l}67.7 \\
(5.8)\end{array}$ \\
\hline $\begin{array}{l}\text { Compensation } \\
\text { coupons } \ldots \ldots . .\end{array}$ & $\begin{array}{c}.0 \\
(.0)\end{array}$ & $\begin{array}{c}2.3 \\
(3.1)\end{array}$ & $\begin{array}{c}17.3 \\
(10.0)\end{array}$ & $\begin{array}{c}64.2 \\
(49.3)\end{array}$ & $\begin{array}{l}18.5 \\
(3.9)\end{array}$ & $\begin{array}{l}41.6 \\
(26.3)\end{array}$ & $\begin{array}{c}6.8 \\
(5.7)\end{array}$ & $\begin{array}{l}150.7 \\
(13.0)\end{array}$ \\
\hline $\begin{array}{l}\text { Average exchange } \\
\quad \text { rate } \ldots \ldots \ldots \ldots . .\end{array}$ & 74.7 & 79.0 & 91.9 & 105.2 & 125.7 & 152.6 & 180.0 & $\ldots$ \\
\hline
\end{tabular}

NoTE. - Data are from the State Privatization and Asset Management Agency as reported in van Elkin $(1998 b$, p. 64). Percentage of total revenues are in parentheses.

resented more than $60 \%$ of the SPA's revenues for that year. By 1994 , foreign sales dropped to less than the equivalent of $\$ 125$ million, representing only $10 \%$ of the SPA's revenues. At the same time, the subsidized sale of enterprises to Hungarian citizens picked up dramatically. In 1992, sale by means of E-credits and compensation vouchers accounted for slightly more than $15 \%$ of the SPA's revenues. In 1994, however, sales subsidized by means of such credits and coupons exceeded cash sales by a large margin, accounting for more than 70\% of the SPA's "revenues" for that year. As these statistics make clear, the government had lived up to its promise to restrict foreign investment in favor of policies designed to promote the formation of a domestic bourgeoisie. By the end of 1994, foreign investment had dropped precipitously while the sale of firms to Hungarian citizens accounted for the bulk of privatization transactions.

The response to the government's shift in policies on the part of international agencies was swift and severe. Officials from IMF, EBRD, and EU condemned the failure of the Hungarian government to make progress on the privatization front. When these criticisms failed to bring about the desired results, the agencies in question cut off assistance to Hungary. The IMF suspended release of further tranches of aid, and the EBRD followed suit. As a result, Hungary's position within international financial markets deteriorated considerably. Its credit rating declined, making the cost of obtaining capital on international bond markets higher. In addition, its refusal to open up key economic sectors to foreign pen- 
etration was met with condemnation from EU officials (Denton 1993; MTI-Econews 1995a; Kornai 1997). Ultimately the policy shift proved unsustainable. Because Hungary remained dependent on foreign financial assistance, the government could ill afford to appear on the IMF's blacklist. In addition, to many Hungarians the benefits associated with flouting the EU's standards regarding foreign ownership did not appear to measure up to the costs associated with failure to gain membership in that body. During the election campaign of 1994, the Socialist Party took issue with the Antall government's privatization policies, promising to put an end to Hungary's isolation within the international community. Ironically, the victory of the Socialists marked a return to conformity to standards imposed by international agencies.

\section{The Final Phase, 1995-97}

The election of the Socialists to power in the fall of 1994 marked the end of efforts to promote domestic ownership of firms in key economic sectors. The program of subsidizing sales of state-owned enterprises to Hungarian citizens was quickly replaced by one that reemphasized sales to foreign multinationals. As table 3 shows, in 1995 the E-credit and compensation vouchers accounted for less than $5 \%$ of privatization revenue for that year, down from approximately $70 \%$ in $1994 .{ }^{13}$ The decline was complemented by a dramatic increase in cash sales, particularly cash sales to foreign parties. According to table 1, revenues from cash sales increased by a factor of 10 in real terms, from the equivalent of approximately $\$ 350$ million in 1994 to $\$ 3.6$ billion in 1995 , with sales to foreigners accounting for more than $90 \%$ of the total cash figure. What might have led a government made up largely of reformed communists to implement a set of policies that so clearly favored foreign capital?

As noted above, previous efforts to promote domestic sales of stateowned enterprises had resulted in the deterioration of Hungary's position within international financial circles which in turn had contributed to a serious downturn in the domestic economy. By the time the Socialists took office, real wages were falling, unemployment was above $10 \%$, inflation was at $30 \%$, the current account deficit had climbed to more than $\$ 300$ million (almost $10 \%$ of GDP), and the budget deficit exceeded $8 \%$ of GDP (Cottarelli 1998, pp. 13-17). The Socialists made good on their pledge to reverse this situation and immediately entered into negotiations with in-

\footnotetext{
${ }^{13}$ The use of compensation vouchers increased in 1996 due to the fact that the Socialist government was obliged to redeem coupons issued prior to its assumption of power. By 1997 , however, compensation vouchers once again accounted for far less than $10 \%$ of privatization revenues.
} 
ternational lenders and the EU. Agreement was reached with the IMF in 1995, and the government was obliged to speed up privatization and to accept strict limits on the size of the budget and current account deficits in exchange for a new $\$ 300$ million loan from the agency. The signing of this agreement led in turn to the release of funds from the EBRD, which began investing money in Hungary with renewed zeal (Marsh 1995; MTIEconews $1995 b$, 1994). Finally, the Socialist government signed an agreement with the EU in 1995 that committed Hungary to a set of sweeping reforms-particularly in regard to the privatization banks and utility companies, which the previous government had resisted (OECD 1999). Crisis conditions, in other words, had pushed Hungary back into the arms of international lenders and the $\mathrm{EU}$, entities that were prepared to welcome the country back into the fold only on the condition that it abide by neoliberal principles.

Of special interest to international agencies was the privatization of the banking sector. From the perspective of the IMF and the EBRD, private ownership of financial institutions in postcommunist countries was necessary in order to put an end to the type of "subterranean redistribution" that resulted from the tendency of state-owned banks to extend loans to loss-making state-owned enterprises (King 2000). According to this view, the Hungarian economy could not be based on market principles until bank privatization had been achieved. For the IMF and EU, however, it was not enough to force the state to divest itself of shares in Hungarian commercial banks; international agencies were unanimous in their call for the elimination of restrictions on foreign ownership of Hungarian financial institutions (European Commission 1995; Borish and Noël 1996; EBRD 1997). Since 1990, the Hungarian government had been enforcing a law that prohibited foreign parties from owning more than $10 \%$ of a given bank without special permission-and up to 1995 that permission had never been granted. This law was supplemented by legislation passed in 1992 that prohibited any single entity from owning more than $25 \%$ of a given bank (Lakatos 1991). Following the conclusion of negotiations with the EU in 1995, the Hungarian parliament repealed these restrictive laws and, in accordance with EU standards, passed new legislation permitting unlimited foreign ownership of banks and other financial institutions, such as insurance companies and mutual funds (van Elkin 1998a).

Foreign intervention in the privatization of the banking sector was not limited, however, to the elimination of legal restrictions on foreign ownership. Following the repeal of the laws in question, international lending agencies such as the EBRD began to intervene directly in the privatization of banks. Over the course of 1995, for example, the EBRD purchased minority ownership stakes in five of Hungary's six main commercial banks. The purpose of this action was twofold: first, to inject capital for 
use in restructuring the banks' operations, and second, to send a signal to potential investors that the reform of the banking sector was proceeding as planned (European Report 1997; Robinson 1997). The strategy worked. By 1997, all but one of Hungary's commercial banks had been privatized, with majority ownership rights passing into the hands of large European financial establishments (EBRD 1998; van Elkin 1998a). Largely as a result of international pressure, Hungary became the first country within the former Soviet bloc to put banking practices on an entirely new footing.

The privatization of telecommunication and energy firms followed the same pattern. International lending agencies and the EU demanded the elimination of restrictions on foreign ownership of firms in these sectors. Upon conclusion of negotiations with the IMF and the EU in 1995, the government removed state-owned telecommunications and energy companies from the list of firms to remain under long-term state ownership. Massive loans from the EBRD and the World Bank quickly materialized to modernize these sectors and to attract additional foreign investors; not surprisingly, foreign capital came pouring in. In 1995 alone, foreign multinationals invested $\$ 2$ billion in Hungarian energy companies, acquiring majority ownership rights over all of Hungary's electricity producers and distributors and all of Hungary's gas distributors as well as minority ownership rights in MOL, Hungary's state-owned gas producer. In addition, two multinationals acquired controlling interest in MATAV, the state-owned telecommunications company that in and of itself accounted for more the 3\% of the country's GDP (Financial Times 1997, 1999).

The statistics presented in table 4 underscore the extent to which foreign multinationals came to occupy many of the Hungarian economy's "commanding heights." The table displays majority ownership of firms in the following sectors-energy, telecommunications, finance, and basic industry-that were placed into the category of long-term state ownership in 1992. Despite the intentions of state officials to retain control over firms in these sectors, by 1999 foreign multinationals had assumed control of two-thirds of the enterprises. This development is in line with estimates that, by the late 1990s, foreign capital controlled two-thirds of the economic assets in the manufacturing sector, $90 \%$ in telecommunications, $60 \%$ in energy production and distribution, and $70 \%$ in finance (MTIEconews 1997 d). Within 10 years of the collapse of state socialism, in other words, control of key sectors of the economy had been ceded to foreign multinationals.

Given the fact that pressures applied by international agencies had largely eliminated restrictions on foreign ownership by 1997 , it would be easy to describe changes to the property rights structure in Hungary in terms of progressive conformity to internationally imposed standards. Such an interpretation would overlook, however, the significance of earlier 
American Journal of Sociology

TABLE 4

OWNership of Firms Placed into Permanent State OWNership (INDUStrial

Firms, Firms IN ENERgY SECTOR, AND BANKS ONLY), 1999

\begin{tabular}{cccccc}
\hline & \multicolumn{5}{c}{ MAJority OwNER } \\
\cline { 2 - 6 } SECtor & $N$ of Firms & State & Foreign & Domestic & $\begin{array}{c}\text { Joint Foreign } \\
\text { and Domestic }\end{array}$ \\
\hline Industry $\ldots \ldots \ldots \ldots \ldots \ldots$ & 12 & 2 & 7 & 2 & 1 \\
Energy $\ldots \ldots \ldots \ldots \ldots \ldots$. & 7 & 1 & 6 & 0 & 0 \\
Banking $\ldots \ldots \ldots \ldots \ldots \ldots$ & 7 & 2 & 5 & 0 & 0 \\
Telecommunications .... & 1 & & 1 & 0 & 0 \\
Total .............. & 27 & 5 & 19 & 2 & 1 \\
\hline
\end{tabular}

Note. - Data are from company reports and business press.

property rights actions on the part of the state. Not only did government officials in Hungary maintain barriers to foreign investment for much of the 1990s, they also adopted, at considerable cost in terms of their standing in the international financial community, policies that subsidized the sale of state-owned assets to domestic parties. Although these policies were only in effect for a few years, they were nevertheless applied extensively enough to have fostered the emergence of a class of domestic owners. Furthermore, because ownership rights were in many instances transferred to enterprise insiders, the ranks of these owners included many individuals with a detailed understanding of the challenges their firms faced in finding a niche in regional and global markets. Although it is still too early to determine the extent to which the channeling of ownership rights to Hungarian nationals has fostered local capital accumulation, it seems reasonable to argue that the privatization policies pursued by government officials in Hungary kept open lines of development that would have been closed had the market-driven approach favored by international agencies been implemented, particularly since, as many observers have noted, the shock-therapy approach toward privatization would in all likelihood have led to the exit of a large number of viable firms from the market (Leijonhufvud and Rühl 1997; King 2002). The fact that state actors in Hungary ultimately conceded to the demands of international agencies should therefore not be allowed to obscure their efforts to shape the development of the domestic economy through their property rights actions.

\section{CONCLUSION}

Evolutionary accounts of property transformation in postcommunist Hungary have ignored evidence of the rapid diffusion of private ownership 
rights in Hungary. As our empirical analysis has shown, since the collapse of state socialism in 1989 Hungary has witnessed not a blurring of the distinction between state and private ownership but a transition from state to private ownership. We explain this transition by calling attention to two developments that have been ignored in most sociological accounts of property transformation in Hungary. First, state actors in that country actively promoted the emergence of a domestic ownership class by sub-. sidizing the sale of state-owned enterprises to Hungarians. Second, a massive amount of direct foreign investment has entered Hungary over the past 10 years, particularly after 1995 when the government implemented a stabilization package that eliminated many restrictions on direct foreign investment. Taken together, these two developments have placed ownership of a large majority of medium-sized to large enterprises in the hands of clearly identifiable private parties. Capitalism in Hungary is being made, in other words, with rather than without capitalists.

Drawing on insights from comparative political economy, we explain the diffusion of private ownership rights in Hungary, and in particular the distribution of these rights between foreign and domestic parties, in terms of a contest between the state and international agencies over the course of economic development in Hungary. Evolutionary accounts have had little to say about the role of the state and international agencies in property transformation, emphasizing instead the manner in which local actors, particularly enterprise directors, constructed new institutions on the basis of routines and practices dating back to the state-socialist period. We argue, however, that a theoretical approach that fails to put the state and supra-state agencies at the center of the analysis cannot possibly explain the transformation of ownership rights in Hungary. As our analysis has shown, state actors in Hungary resisted pressures to allow foreign capital free sway in the country by maintaining barriers to FDI and subsidizing the sale of state enterprises to domestic parties. Because of these efforts a very substantial proportion of formerly state-owned enterprises were in the hands of Hungarian citizens by the late 1990s. Ultimately, however, pressures applied by a host of international agencies combined with deteriorating economic conditions forced government officials in Hungary to abandon these efforts. The subsidized sale of state enterprises to Hungarian nationals came to a halt, barriers to FDI were lifted, and foreign capital came to control most of the Hungarian economy's commanding heights.

On the surface, these developments appear to confirm the arguments of competition state theorists. After all, the agreements into which Hungary has entered with international agencies such as the IMF and EU rule out recourse to a broad range of policy options on which states have historically relied to influence economic activities. Despite considerable 
evidence of conformity with neoliberal principles on the part of government officials in Hungary, we nevertheless insist that the competition state perspective cannot be usefully applied to property transformations in that country. Contrary to the expectations of theorists in the competition state camp, government officials in Hungary did not play the role of "suitors" of foreign capital but instead enforced for a number of years policies that were decidedly unfriendly toward foreign multinationals seeking entry into the country. The property rights actions of state actors in Hungary are much better explained, we argue, from the developmental state perspective. While there is no doubt that the Hungarian state has experienced considerable erosion in its ability to influence economic activities since becoming integrated into world markets, the analysis presented here has demonstrated that government officials in that country retained significant capacity to shape economic developments through the allocation of ownership rights over state enterprises. Although it is still too early to determine with any precision the economic impact of these actions, it is not unreasonable to argue that the channeling of assets to Hungarian nationals has resulted in higher rates of domestic capital accumulation than would have been obtained had the shock-therapy approach to privatization been fully implemented. Thus we maintain that, even though they were forced in the long run to adopt the neoliberal formulas put forward by international agencies, state actors in Hungary were nevertheless able to affect in a durable way the integration of their country into the world economy through their property rights actions.

Up to now, researchers studying postcommunist Eastern Europe have generally rejected the developmental state approach either on the grounds that control of economic assets has devolved to local actors or that international agencies have imposed constraints on government officials that rule out effective economic intervention on the part of the state. Both of these arguments emphasize the organizational weakness of postcommunist states in Eastern Europe and both, we argue, are misplaced. Studies that have highlighted the incapacity of postcommunist governments to influence economic processes have overlooked the manner in which the privatization process itself has provided state actors with new means of shaping economic developments. For this reason, we believe that the property rights framework outlined here, while not universally relevant, may be usefully applied to other formerly state-socialist societies, particularly those in Eastern Europe, where state actors have possessed formal ownership rights over the bulk of their country's productive assets and been under enormous pressure to open their countries up to foreign direct investment. Under these circumstances, we expect that state actors in such countries as Poland, the Czech Republic, and Slovenia have followed the lead of their counterparts in Hungary in relying greatly on property 
rights actions to further developmental goals. In short, we believe that Hungary is not an isolated case and that a proper emphasis on the property rights actions of government officials in postcommunist societies would lead researchers to recognize that the state continues to play a leading role in processes of capital accumulation in such societies despite the efforts of international organizations to limit its economic role.

\section{REFERENCES}

Aghion, Phillippe. 1991. "The European Bank for Reconstruction and Development." Pp. 251-52 in The Transition to a Market Economy. Vol. 1: Broad Issues, edited by Paul Marer and Salvatore Zecchini. Paris: OECD.

Amsden, Alice. 1989. Asia's Next Giant: South Korea and Late Industrialization. Oxford: Oxford University Press.

Amsden, Alice, Jacek Kochanowicz, and Lance Taylor. 1994. The Market Meets Its Match: Restructuring the Economies of Eastem Europe. Cambridge, Mass: Harvard University Press.

Becker, David. 1983. The New Bourgeoisie and the Limits of Dependency: Mining, Class, and Power in 'Revolutionary' Peru. Princeton, N.J.: Princeton University Press.

Bennett, Douglas C., and Kenneth E. Sharpe. 1985. Transnational Corporations versus the State: The Political Economy of the Mexican Auto Industry. Princeton, N.J.: Princeton University Press.

Bobinski, Christopher. 1997. "EU Conditions for Aid under Attack." Financial Times, December 22, p. 2.

Boltho, Andrea. 1996. "Has France Converged on Germany? Policies and Institutions since 1958." Pp. 89-104 in National Diversity and Global Capitalism, edited by Suzanne Berger and Ronald Dore. Ithaca, N.Y.: Cornell University Press.

Borish, Michael S., and Michel Noël. 1996. "Private Sector Development in the Visegrad Countries." IMF Finance and Development 33 (4): 1-4.

Campbell, John L., and Leon L. Lindberg. 1990. "Property Rights and the Organization of Economic Activity by the State." American Sociological Review 55:634-47.

Campbell, John L., and Ove K. Pedersen. 1996. "The Evolutionary Nature of Revolutionary Change in Postcommunist Europe." Pp. $207-49$ in Legacies of Change: Transformations of Postcommunist European Economies, edited by John L. Campbell and Ove K. Pedersen. New York: Aldine de Gruyter.

Canning, Anna, and Paul Hare. 1994. "The Privatization Process-Economic and Political Aspects of the Hungarian Approach." Pp. 176-217 in Privatization in Central and Eastem Europe, edited by Saul Estrin. London: Longman.

Cerny, Philip G., ed. 1993. Finance and World Politics: Markets, Regimes and States in the Post-Hegemonic Era. Brookfield, Ver.: Edward Elgar.

Cottarelli, Carlo. 1998. "Macroeconomic and Structural Adjustment during 1995-97: An Overview." Pp. 3-18 in Hungary: Economic Policies for Sustainable Growth, edited by Carlo Cottarelli et al. International Monetary Fund Occasional Paper 159. Washington, D.C.: International Monetary Fund.

Crane, Keith. 1991. "Property Rights Reform: Hungarian Country Study." Pp. 69-94 in Transformation of Planned Economies: Property Rights Reform and Macroeconomic Stability, edited by Hans Blommenstein and Michael Marrese. Paris: OECD.

Csite, A., and I. Kovách. 1999. "The End of Post-Socialism: The Structure and Efficiency of the Ownership of Hungarian Large Companies in 1997." Acta Oeconomica 50 (1-2): 57-88. 
Denton, Nicholas. 1990. "Unheroic Hungarian Tackles an Heroic Task." Financial Times, April 10, sec. 1, p. 2.

p. 4.

EBRD. 1997. "Progress in Market-Oriented Transition." EBRD Transition Report (November): $10-36$.

. 1998. "Progress in Market-Oriented Transition." EBRD Transition Report (November): 22-38.

European Commission. 1995. Preparation of the Associated Countries of Central and Eastern Europe for Integration into the Internal Market of the Union. Luxembourg: Office for Official Publications of the European Communities.

- 1999. Regular Report 1998 from the Commission on Hungary's Progress towards Accession. Luxembourg: Office for Official Publications of the European Communities.

European Report. 1997. "European Bank for Reconstruction and Development Aids Hungarian and Polish Reform," no. 2223 (May 14).

Evans, Peter. 1979. Dependent Development: The Alliance of Multinational, State, and Local Capital in Brazil. Princeton, N.J.: Princeton University Press.

- 1995. Embedded Autonomy: States and Industrial Transformation. Princeton. N.J.: Princeton University Press.

Eyal, Gil, Iván Szelényi, and Eleanor Townsend. 1998. Making Capitalism without Capitalists: Class Formation and Elite Struggles in Post-Communist Central Europe. London: Verso.

Financial Times. 1997. "MOL Increases Share Offering." May 22, p. 40. 8, p. 31 .

Fligstein, Neil. 1996. "The Economic Sociology of the Transitions from Socialism." American Journal of Sociology 101 (4): 1074-81.

Frydman, Roman, Kenneth Murphy, and Andrzej Rapaczynski. 1996. “Capitalism with a Comrade's Face." Transition 2:2.

Gowan, Peter. 1995. "Neo-Liberal Theory and Practice for Eastern Europe." New Left Review 213:3-60.

Haggard, Stephan. 1995. Developing Nations and the Politics of Global Integration. Washington, D.C.: The Brookings Institution.

Held, David, et al. 1999. Global Transformation: Politics, Economics, and Culture. Stanford, Calif.: Stanford University Press.

Helleiner, Eric. 1994. States and the Reemergence of Global Finance: From Bretton Woods to the 1990s. Ithaca, N.Y.: Cornell University Press.

Hunya, Gábor. 2000. "The Relationship between FDI, Privatization and Structural Change in Central and Eastern European Countries." Pp. 189-204 in Privatization, Corporate Governance and the Emergence of Markets, edited by Eckehard F. Rosenbaum, Frank Bönker, and Hans-Jürgen Wagener. New York: St. Martin's Press.

Johnson, Chalmers. 1982. MITI and the Japanese Miracle: The Growth of Industrial Policy, 1925-1975. Stanford, Calif.: Stanford University Press.

Karsai, Judit, and Mike Wright. 1994. "Accountability, Governance, and Finance in Hungarian Buy-outs." Europe-Asia Studies 46:997-1016.

King, Lawrence. 2000. The Basic Features of Postcommunist Capitalism: Firms in Hungary, the Czech Republic, and Slovakia. Westport, Conn.: Praeger.

. 2002. "Postcommunist Divergence: A Comparative Analysis of the Transition to Capitalism in Poland and Russia." Studies in Comparative International Development, in press.

Kornai, János. 1992. The Socialist System: The Political Economy of Communism. Princeton, N.J.: Princeton University Press. 
- 1997. "Adjustment without Recession: A Case Study of Hungarian Stabilization." Pp. 123-51 in Lessons from the Economic Transition: Central and Eastern Europe in the 1990s, edited by Salvatore Zecchini. Dordrecht: Kluwer Academic Publishers.

Lajtai, György. 1997. "Successful Waves of Employee Ownership in Hungary." Pp. 136-64 in Privatization Surprises in Transition Economies: Employee-Ownership in Central and Eastern Europe, edited by Milica Uvalic and Daniel VaughanWhitehead. Cheltenham: Edward Elgar.

Lakatos, Maria. 1991. "Hungary's Banks Focus on Parliamentary Debate." Eastern Europe Report 1 (34): 7.

Leijonhufvud, Axel, and Christof Rühl. 1997. Russian Dilemmas. London: EBRD.

Major, Iván, Cristiano Vezzoni, and Andrea Szavaletz. 1999. "Company Restructuring after Privatization in Hungary between 1988 and 1997." Pp. 155-302 in Privatization and Economic Performance in Central and Eastern Europe: Lessons to be Learnt from Western Europe, edited by Ivan Major. Cheltenham: Edward Elgar.

Marsh, Virginia. 1995. "Hungarian Coalition Left Exposed." Financial Times, September 21, p. 3.

Matolcsy, Gyorgy. 1990. "Defending the Cause of Spontaneous Reform of Ownership." Acta Oeconomica 42:1-22.

Mihályi, Péter. 2000. "Corporate Governance during and after Privatization: The Lessons from Hungary." Pp. 189-204 in Privatization, Corporate Governance and the Emergence of Markets, edited by Eckehard F. Rosenbaum, Frank Bönker, and Hans-Jürgen Wagener. New York: St. Martin's Press.

Mills, Jennie. 1991. "The Shape of Agreements to Come." Financial Times, December 5 , sec. 1, p. 42.

Móra, M. 1991. "The (Pseudo-) Privatization of State-Owned Enterprises: Changes in Organizational and Proprietory Firms, 1987-1990." Acta Oeconomica 43:37-58.

Moran, T. H. 1974. Multinational Corporations and the Politics of Dependence: Copper in Chile. Princeton, N.J.: Princeton University Press.

MTI-Econews. 1990a. "Government Discusses Property Policy Guidelines for 1991." December 3.

December 4.

-1991. "Proposal on Privatization Strategies in Hungary." June 3.

—. 1992a. "Hungary's External Financing." March 24.

- 1992b. "Reduced E-Credit Interest." December 11.

— 1993a. "Privatization of the Tobacco Industry." November 12.

- 1993b. "Privatization Policy Guidelines." June 16.

- 1994. "Compensation Review." December 29.

—_. 1995a. "EBRD-Hungary on its Economic Policy." April 9.

- 1995b. "The IMF's Five Points." October 18.

- 1997a. "Contract for Ajka Aluminum sale signed." July 11.

- 1997b. "EBRD-Hungarian National Strategy." December 22.

- 1997c. "EBRD Takes a Greater Role in Hungarian Projects." December 5.

- 1997d. "Efforts to Promote Domestic Capital." October 16.

- 1997e. "Hungary Prepares for EU Accession Talks." December 24.

Murrell, Peter. 1992. "Evolution in Economics and in the Economic Reform of the Centrally Planned Economies." Pp. 35-53 in The Emergence of Market Economies in Eastern Europe, edited by Christopher Clague and Gordon C. Rausser. Cambridge, Mass.: Blackwell.

Nielsen, Klaus, Bob Jessop, and Jerzy Hausner. 1995. "Institutional Change in PostSocialism." Pp. 3-44 in Strategic Choice and Path-Dependency in Post-Socialism: Institutional Dynamics in the Transformation Process, edited by Jerzy Hausner, Bob Jessop, and Klaus Nielsen. Brookfield, Vt.: Edward Elgar. 
OECD. 1999. OECD Economic Surveys, 1998-1999: Hungary. Paris: OECD.

Ohmae, Kenichi. 1990. The Borderless World. New York: Harper.

Pechota, Vratislav, ed. 1990. Central and Easterm European Legal Materials. Ardsleyon-Hudson, N.Y.: Transnational Juris Publications.

Piore, Michael, and Charles Sabel. 1984. The Second Industrial Divide. New York: Basic Books.

Powell, Walter W. 1990. "Neither Market nor Hierarchy: Network Forms of Organization." Research in Organizational Behavior 12:295-336.

Poznanski, Kazimierz Z. 1995. "Introduction." Pp. ix-xxiii in The Evolutionary Transition to Capitalism, edited by Kazimierz Z. Poznanski. Boulder, Colo: Westview Press.

Robinson, Anthony. 1992. "Survey of Hungary." Financial Times, October 29, 31. 9, 2.

Róna-Tas, Akos. 1997. The Great Surprise of the Small Transformation: The Demise of Communism and the Rise of the Private Sector in Hungary. Ann Arbor: University of Michigan Press.

Sagi, Matild. 1993. "1992 Survey of Managers.” MRDF. Budapest: TARKI (producer and distributor).

Smith, Adrian, and John Pickles, eds. 1998. Theorising Transition: The Political Economy of Post-Communist Transformation. London: Routledge.

Stark, David. 1996. "Recombinant Property in East European Capitalism." American Journal of Sociology 101 (4): 993-1027.

Stopford, John M., and Susan Strange. 1992. Rival States, Rival Firms: Competition for World Market Shares. Cambridge: Cambridge University Press.

Szelényi; Ivan, and Imre Kováchs. 1998. "1997 Survey of Management of Leading Hungarian Companies." MRDF. Budapest: Institute of Political Science (producer and distributor).

Tóth, István János. 1997. "Inter-enterprise Ownership Links in Hungary." Acta Oeconomica 49:365-96.

van Elkin, Rachel. 1998a. "Financial Markets in Hungary." Pp. 81-91 in Hungary: Economic Policies for Sustainable Growth, edited by Carlo Cottarelli et al. International Monetary Fund Occasional Paper 159. Washington, D.C.: IMF.

- 1998b. "Privatization." Pp. 63-7 in Hungary: Economic Policies for Sustainable Growth, edited by Carlo Cottarelli et al. International Monetary Fund Occasional Paper 159. Washington, D.C.: IMF.

Voszka, Éva. 1990. "Rope Walking: Ganz-Danubius Ship and Crane Factory Transformed into a Company." Acta Oeconomica 42:285-302.

- 1993. "Spontaneous Privatization in Hungary." Pp. 89-107 in Privatization in the Transition to a Market Economy: Studies of Preconditions and Policies in Eastern Europe, edited by John S. Earle, Roman Frydman, and Andrej Rapaczynski. New York: St. Martin's Press.

- 1994. "The Revival of Redistribution in Hungary." Acta Oeconomica 46 (1-2): 63-78.

1995. "Centralization, Re-Nationalization, and Redistribution: Government's Role in Changing Hungary's Ownership Structure." Pp. 287-308 in Strategic Choice and Path Dependency in Post-Socialism: Institutional Dynamics in the Transformation Process, edited by Jerzy Hausner, Bob Jessop, and Klaus Nielsen. Brookfield, Vt.: Edward Elgar.

—. 2000. "Privatization in Hungary: Results and Open Issues." (http:/l www.cipe.org. ert/e32/e32_03.html).

Wade, Robert. 1990. Governing the Market: Economic Theory and the Role of Government in East Asian Industrialization. Princeton, N.J.: Princeton University Press. 
Wapenhans, Willi. 1990. "The Challenge of Economic Reforms in Eastern Europe." IMF Finance and Development 27 (4): 2.

World Bank. 1995. Hungary: Structural Reforms for Sustainable Growth. Washington, D.C.: World Bank. Bank.

1999. Hungary: On the Road to the European Union. Washington, D.C.: World 